\title{
湿潤 $\mathrm{CO}_{2}$ 環境中での $13 \% \mathrm{Cr}$ 鋼の腐食に及ぼす $\mathrm{C}$ 量と金属組織の影響*
}

\author{
原卓也 ${ }^{* *}$, 朝日 均** \\ ** 新日本製鐵株式会社技術開発本部鉄鋼研究所鋼材第二研究部
}

\author{
Effects of Carbon Content and Microstructure on Corrosion \\ Rate of $13 \%$ Chromium Steel in Wet $\mathrm{CO}_{2}$ Environments* \\ Takuya Hara**, Hitoshi Asahi** \\ ** Steel Products Lab.-II, Steel Research Laboratory \\ Technical Development Bureau, Nippon Steel Corporation
}

\begin{abstract}
Effects of carbon content and microstructure on corrosion rate of $13 \%$ chromium steel were investigated in wet $\mathrm{CO}_{2}$ environments. First, corrosion rates of ferrite, martensite and tempered martensite were different from each other in $13 \%$ chromium steel. Corrosion rate of tempered martensite was the highest and that of martensite was the lowest. Second, corrosion rate of $13 \%$ chromium steel was indicated as the summation of the product of corrosion rate for each microstructure by its areal fraction.
\end{abstract}

Key words: $13 \%$ chromium steel, $\mathrm{CO}_{2}$ corrosion, microstructure, ferrite, martensite, tempered martensite, sweet environment

\section{1. 緒 言}

$13 \% \mathrm{Cr}$ 鋼の耐 $\mathrm{CO}_{2}$ 腐食性は良好で，耐食鋼としては 比較的安価であることから, $\mathrm{CO}_{2}$ を産出する油井, ガ ス井で $13 \% \mathrm{Cr}$ 鋼が多く使用されている。油井管として は C を $0.2 \%$ 添加した AISI $42013 \% \mathrm{Cr}$ 鋼が最も一般 的である。AISI 420 鋼は焼戻し処理を施すので, $\mathrm{Cr}$ 炭 化物を形成し, 母相中の有効 $\mathrm{Cr}$ 量を減少させ, 而 $\mathrm{CO}_{2}$ 腐食性を劣化させる ${ }^{1)}$ 。従って, 耐 $\mathrm{CO}_{2}$ 腐食性を 向上させるためには $\mathrm{C}$ 量はできるだけ少ない方が望ま しい。C 量が $0.1 \%$ まで減少した AISI $41013 \% \mathrm{Cr}$ 鋼が

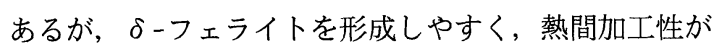
劣るため製造上の点で問題がある。そこで， $13 \% \mathrm{Cr}$ 鋼 の低 $\mathrm{C}$ 化による $\mathrm{CO}_{2}$ 腐食特性向上の研究開発が近年多 く行われている2) 6)。しかしながら, $13 \% \mathrm{Cr}$ 鋼の $\mathrm{CO}_{2}$ 腐食に及ぼす組織の影響については報告例がない。

炭素鋼の $\mathrm{CO}_{2}$ 腐食に及ぼす組織の影響についての研

* 腐食防食' 95 (東京, 1995 年) で発表

** T293-8511 富津市新富 20-1 (20-1, Shintomi, Futtu, 293-8511, Japan)
究例は幾つかある。小川らは ${ }^{7)}, \mathrm{CO}_{2}$ 分圧 $0.1 \mathrm{MPa}$, $25^{\circ} \mathrm{C}$ の静止人工海水環境では, 焼戻しマルテンサイト 組織よりもフェライト・パーライト組織の方が腐食速度 が大きくなると述べている。一方, 植田ら ${ }^{8), 9)}$ は, $\mathrm{CO}_{2}$ 分圧 $0.3 \mathrm{MPa}, 60^{\circ} \mathrm{C}$, 流速 $2.5 \mathrm{~m} / \mathrm{s}$ の環境では, 焼 戻しマルテンサイト組織よりもフェライト・パーライト 組織の方が腐食速度が小さくなると述べており, 様々な 説がある。

本報告では， AISI $42013 \% \mathrm{Cr}$ 鋼をべースとし，C 量 を変えた鋼を用いて, $\mathrm{CO}_{2}$ 腐食に及ぼす組織の影響に ついて検討した。

\section{2. 実験方法}

\section{1 試 験 材}

$\mathrm{C}$ 量を変化させた 8 種類の $13 \% \mathrm{Cr}$ 鋼を $300 \mathrm{~kg}$ 真空 溶解（VIM）で溶製し， $50 \mathrm{~kg}$ 鋼塊に分注した。これら の鋼の化学成分を Table 1 に示す。鋼塊の中央で縦割 り切断, $1200^{\circ} \mathrm{C}$ で 1 時間加熱保持した後に, 熱間圧延 によって $12 \mathrm{~mm}$ の鋼板とした。その後熱処理を施し 
Table 1 Chemical compositions of tested steels.

(mass\%)

\begin{tabular}{|c|c|c|c|c|c|c|c|c|c|}
\hline $\mathrm{C}$ & $\mathrm{Si}$ & $\mathrm{Mn}$ & $\mathrm{P}$ & $\mathrm{S}$ & $\mathrm{Cr}$ & $\mathrm{Ni}$ & $\mathrm{Al}$ & $\mathrm{N}$ & $\mathrm{O}$ \\
\hline 0.001 & 0.30 & 0.50 & 0.011 & $<0.001$ & 12.60 & $<0.1$ & 0.018 & 0.0052 & 0.0026 \\
\hline 0.017 & 0.29 & 0.49 & 0.010 & $<0.001$ & 12.49 & $<0.1$ & 0.016 & 0.0051 & 0.0021 \\
\hline 0.047 & 0.29 & 0.49 & 0.010 & $<0.001$ & 12.47 & $<0.1$ & 0.016 & 0.0054 & 0.0021 \\
\hline 0.075 & 0.29 & 0.48 & 0.010 & $<0.001$ & 12.38 & $<0.1$ & 0.016 & 0.0054 & 0.0026 \\
\hline 0.105 & 0.30 & 0.50 & 0.010 & $<0.001$ & 13.03 & $<0.1$ & 0.023 & 0.0050 & 0.0037 \\
\hline 0.130 & 0.30 & 0.49 & 0.010 & $<0.001$ & 13.08 & $<0.1$ & 0.023 & 0.0053 & 0.0021 \\
\hline 0.164 & 0.30 & 0.49 & 0.011 & $<0.001$ & 12.93 & $<0.1$ & 0.023 & 0.0056 & 0.0015 \\
\hline 0.194 & 0.30 & 0.50 & 0.010 & $<0.001$ & 13.07 & $<0.1$ & 0.023 & 0.0056 & 0.0016 \\
\hline
\end{tabular}

た。熱処理条件は焼入れ焼戻しと焼入れままの 2 条件で ある。
(1) $1000^{\circ} \mathrm{C} \times 15 \mathrm{~min} \rightarrow$ 水冷 $700^{\circ} \mathrm{C} \times 60 \mathrm{~min} \rightarrow$ 空冷
(2) $1200^{\circ} \mathrm{C} \times 120 \mathrm{~min} \rightarrow$ 水冷

\section{2 金属組 織}

エタノール飽和ピクリン酸 +5 \%塩酸溶液でエッチン グを行い, 組織観察を行った。

\section{2. $3 \mathrm{X}$ 線回折}

各試料の電解抽出後の残渣をX線回折し, 析出物の同 定を行った。

\section{4 電子顕微鏡観察}

各試料の電解抽出後の残渣を TEM 観察 (Transmission Electron Microscopy) し, 析出物の観察を 行った。また析出物を同定するために EDX (EnergyDispersive X-ray spectrometer）分析を行った。

\section{5 試 験 環 境}

十分脱気した人工海水を試験溶液に用いた。炭酸ガス 分圧は $4 \mathrm{MPa}$ で, 試験温度は $180^{\circ} \mathrm{C}$ である。比液量は $20 \mathrm{~cm}^{3} / \mathrm{cm}^{2}$, 試験時間は 96 時間である。すべて静止 環境中で試験した。

\section{2. $6 \mathrm{CO}_{2}$ 腐食試験}

素材の板厚中央部から $3 \mathrm{~mm}^{t} \times 15 \mathrm{~mm}^{W} \times 20 \mathrm{~mm}^{L}$ の 試験片を加工し, オートクレーブ中での腐食試験に供し た。試験片の表面は\#320エメリー紙で研磨した。試験 片をオートクレーブに挿入後, 事前に十分脱気した試験 溶液を入れ, 密封後 $\mathrm{N}_{2}$ ガスで十分脱気した。所定の温 度に到達した後に, 必要量の試験ガスを圧入した。試験 前の重量と酸洗後の重量の差を試験片表面積と試験時間 で除した值を腐食速度とした。試験後の酸洗は沸騰した $3 \%$ 過マンガン酸カリウム $+18 \%$ 水酸化ナトリウム溶液 に 5 分間浸漬後, 沸騰した $10 \%$ クン酸 IIアンモニウ ム溶液に 5 分間浸漬して行った。

\section{7 電気化学測定}

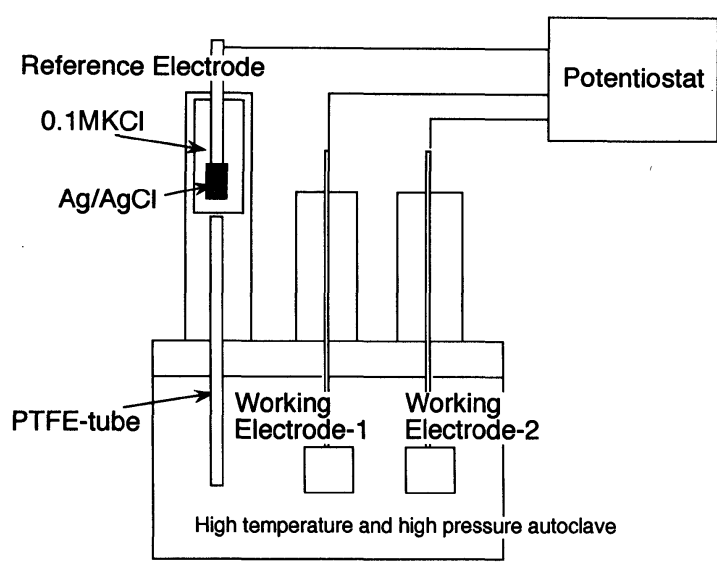

Fig.1 Schematic diagram of galvanic corrosion measurement.

高温高圧オートクレーブ中の 2 つの試料（この場合の アノード/カソード面積比は $1 ： 1$, 試験片面積は 1 $\left.\mathrm{cm}^{2}\right)$ をカップルさせ, ガルバニック電流およびカップ ル電位を測定した。参照電極には圧力平衡型外部照合型 $\mathrm{Ag} / \mathrm{AgCl}$ 電極を使用し, 内部溶液には $0.1 \mathrm{MKCl}$ 水溶 液を用いた。試験条件は 2.6 と同じである。試験ガス を圧入後, 双方の試料の電位が安定した後に試験片どう しをカップルさせ，ポテンシオスタット（東方技研製 potentiostat/galvanostat 2000）を用いてガルバニック 電流，カップ方電位の測定を行った。試験時間は 1 週間 である。試験装置の概要を Fig. 1 に示す。

\section{3. 実 験 結 果}

\section{1 金属組 織}

熱処理条件が (1), (2) の各試験材のミクロ組織を Fig. 2 および Fig. 3 に示す。どちらの熱处理条件ともC 量 が増えると焼戻しマルテンサイトが増えている。Fig. 2 および Fig. 3 から焼戻しマルテンサイトおよびフェ ライトの分率を測定した。焼戻しマルテンサイト分率に 及ぼす C 量の影響を Fig. 4 に示す。熱処理条件 (1), (2) とも， $\mathrm{C}$ 量が $0.05 \%$ まではフェライト量が焼戻しマル テンサイト量よりも多いのに対して，C 量が $0.08 \%$ 以 上になると相分率が逆転している。C量が $0.19 \%$ 以上に なると焼戻しマルテンサイト単相になる。同じ C 量で 比べた場合には, 熱処理条件(2)のフェライト量が(1)の フェライト量よりも多く存在する。 $1000^{\circ} \mathrm{C}$ よりも 1200 ${ }^{\circ} \mathrm{C}$ の方がフェライト量が多いためである ${ }^{10)}$ 。また， C 量が 0.001\%の場合, 熱処理条件(2)では $100 \%$ フライ トである。

\section{3. $2 \mathrm{CO}_{2}$ 腐食試験結果}

熱処理条件が異なる材料の腐食速度に及ぼす C 量の影 響をFig. 5 に示す。 


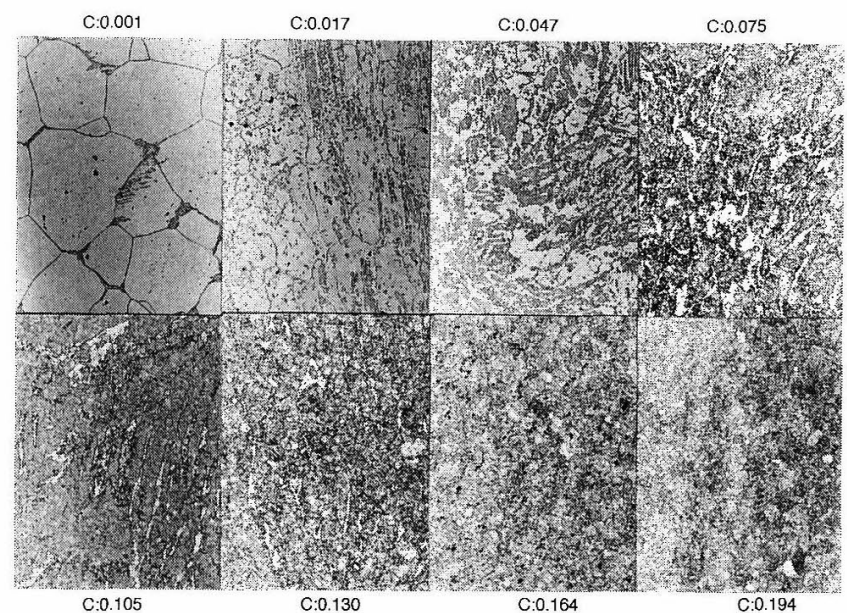

$\stackrel{200 \mu \mathrm{m}}{\longmapsto}$

Fig.2 Optical micrographs of $13 \%$ chromium steels with different carbon content.

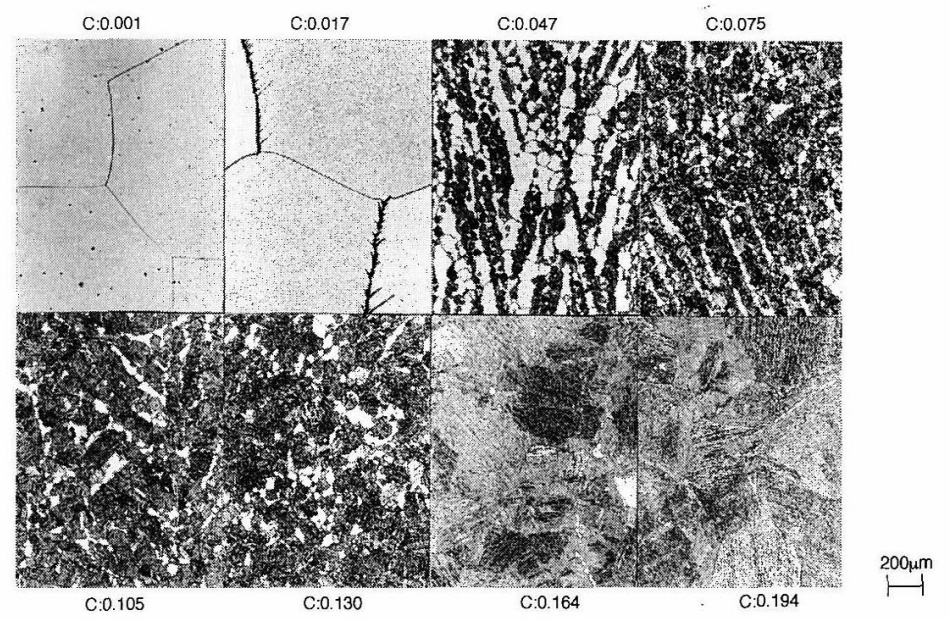

Fig.3 Optical micrographs of $13 \%$ chromium steels with different carbon content.

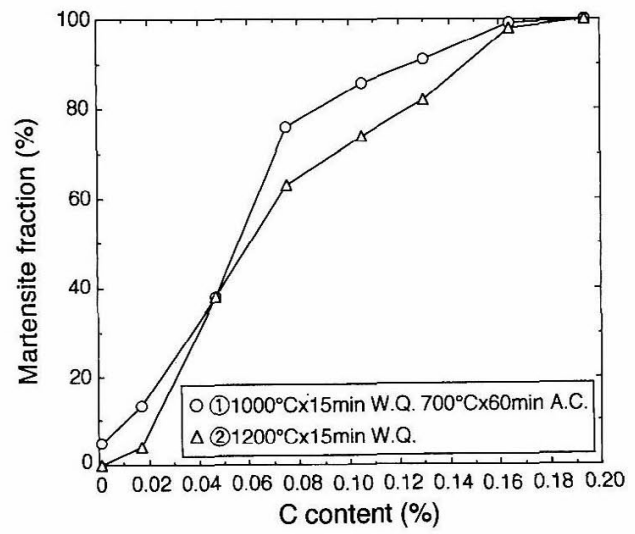

Fig.4 Change of martensite fraction with carbon content.
（1）焼入れ焼戻し材の場合 : 熱処理 条件(1)の場合では，C 量が $0.08 \%$ まで 増加するにつれて腐食速度が増加する。

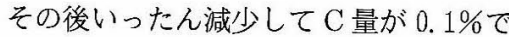
極小值をとった後, 再び $\mathrm{C}$ 量の増加と ともに腐食速度が大きくなる。

（2）焼人れまま材の場合：熱処理条 件(2)の場合では，C 量が $0.2 \%$ まで増加 するにつれて腐食速度が減少した。特に $0.08 \% \mathrm{C}$ と $0.1 \% \mathrm{C}$ との間で腐食速度が 大きく減少している。0.001\%C と 0.017 \%Cではフェライト粒界が腐食してい た。

Table 1 に示したように C 量が 0.08 \%までは $\mathrm{Cr}$ 量が $12.5 \%$ あ゙あのに対し て， C 量が $0.1 \%$ 以上の $\mathrm{Cr}$ 量は $13.0 \%$ であり，Cr 量が 0.5\%異なっている。 そこで $0.5 \% \mathrm{Cr}$ 量に相当する腐食速度 を補正する必要がある。

そこで, $\mathrm{Fe}-\mathrm{Cr}$ 鋼での $\mathrm{CO}_{2}$ 分圧 4 $\mathrm{MPa}, 180^{\circ} \mathrm{C}$, 人工海水中の腐食速度 に及ぼす Cr 量の影響を Fig. 6 に示す。 $\mathrm{Fe}-\mathrm{Cr}$ 鋼の化学成分を Table 2 に示す。 これらの鋼はいずれも鋳造ままで，組織 はすべてフェライト単相である。13\% $\mathrm{Cr}$ 鋼では $1 \% \mathrm{Cr}$ 量あたり腐食速度が0. $23 \mathrm{~mm} / \mathrm{y}\left(50 \mathrm{mg} / \mathrm{dm}^{3} / \mathrm{day}\right)$ 減少する。 すなわち $0.5 \% \mathrm{Cr}$ あたり $0.11 \mathrm{~mm} / \mathrm{y}$ (25 mg/dm $3 /$ day) の腐食速度が減少 する。従って，C量が $0.1 \%$ 以上鋼に おいて， $0.5 \% \mathrm{Cr}$ 量に相当する腐食速度 を増加させ，補正した図を Fig. 7 に示

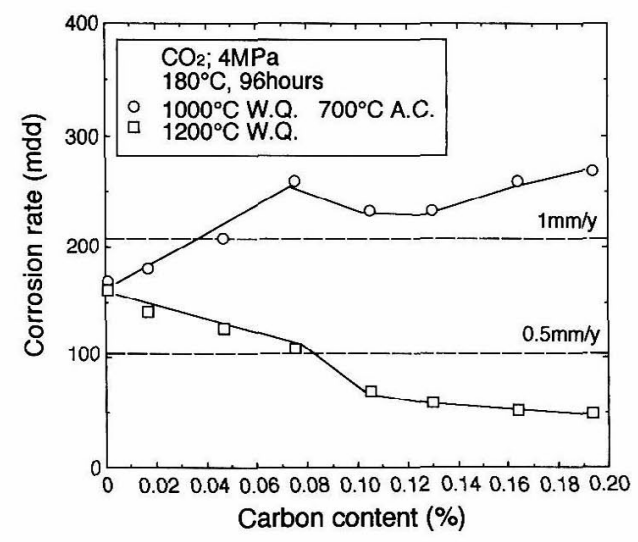

Fig.5 Effect of carbon content on corrosion rate in $\mathrm{CO}_{2}$ environment at $180^{\circ} \mathrm{C}$. 
Table 2 Chemical Compositions of tested steel. (mass\%)

\begin{tabular}{|c|c|c|c|c|c|c|}
\hline $\mathrm{C}$ & $\mathrm{Si}$ & $\mathrm{Mn}$ & $\mathrm{P}$ & $\mathrm{S}$ & $\mathrm{Cr}$ & $\mathrm{N}$ \\
\hline 0.0012 & $<0.01$ & $<0.005$ & 0.003 & $<0.001$ & 10.88 & 0.0010 \\
\hline 0.0013 & $<0.01$ & $<0.005$ & 0.004 & $<0.001$ & 12.84 & 0.0016 \\
\hline 0.0024 & $<0.01$ & $<0.005$ & 0.005 & $<0.001$ & 14.93 & 0.0015 \\
\hline
\end{tabular}

す。今回の条件での腐食速度はフェライト：0.79 $\mathrm{mm} / \mathrm{y}$ (170 mg/dm $\left.{ }^{3} / \mathrm{day}\right)$, 焼戻しマルテンサイト : 1. $37 \mathrm{~mm} / \mathrm{y}$ (295 mg/dm³/day), マルテンサイト : $0.44 \mathrm{~mm} / \mathrm{y}\left(95 \mathrm{mg} / \mathrm{dm}^{3} / \mathrm{day}\right)$ である。すなわちフェ ライトと焼戻しマルテンサイト及びマルテンサイトの腐 食速度に違いがある。

$\mathrm{C}$ 量が $0.164 \%$ 以下では, $1000^{\circ} \mathrm{C}$ から $1200^{\circ} \mathrm{C}$ に加熱した場合には, オーステナイト・フェライト 2 相共存 になる。この時, オーステナイトと フェライトの $\mathrm{C}$ 量は平衡状態図より 決まっている。従って, 熱処理条件(1), (2)の腐食速度 (C.R.) をマルテンサ イト（M), 焼戻しマルテンサイト (T.M)，フェライト $(\alpha)$ のそれぞ れの腐食速度 (C.R.) とその組織分 率の積の和で表すことができる。すな わち,

焼戻し材の場合では

C.R. $=($ C.R. of $\alpha) \times(\alpha$ fraction $)$

+ (C.R. of T.M)

$\times(\mathrm{T} . \mathrm{M}$ fraction $)$

焼入れまま材の場合では

C.R. $=($ C.R. of $\alpha) \times(\alpha$ fraction $)$

+ (C.R. of M)

$\times(\mathrm{M}$ fraction $)$

となる。

これらの式 (1), (2)を用いて焼入れ 焼戻し材および焼入れまま材の腐食速 度を計算した（Fig. 8)。0.5\% Cr 補 正した腐食速度の結果と式(1)，(2)吕 ら求めた計算式の結果が良く一致して いる。

\section{3 電気化学測定結果}

$\mathrm{C}$ 量が $0.001 \%$ 及び $0.2 \%$ の焼戻し 材をカップルさせたときのカップル電 位, ガルバニック電流測定結果を Fig. 9 に示す。C 量が 0.001\%の焼戻 し材の組織は $95 \%$ がフェイトであ

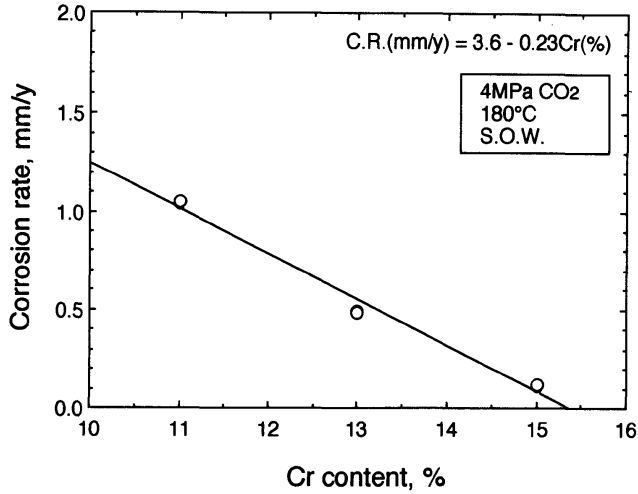

Fig.6 Effect of chromium content on corrosion rate in $\mathrm{CO}_{2}$ environment at $180^{\circ} \mathrm{C}$.

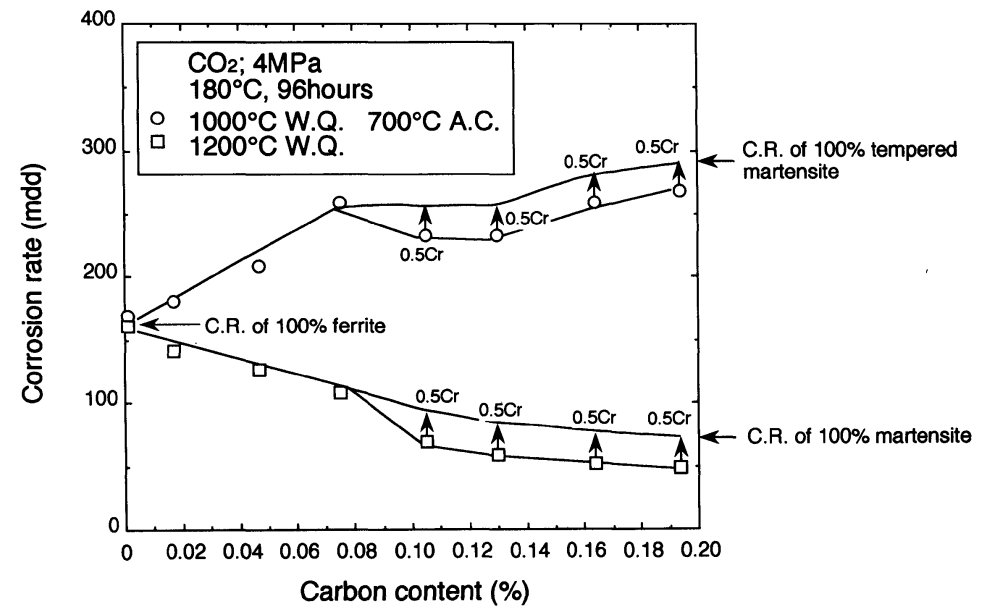

Fig.7 Effect of carbon content on corrosion rate with compensation of $0.5 \%$ chromium decrement.

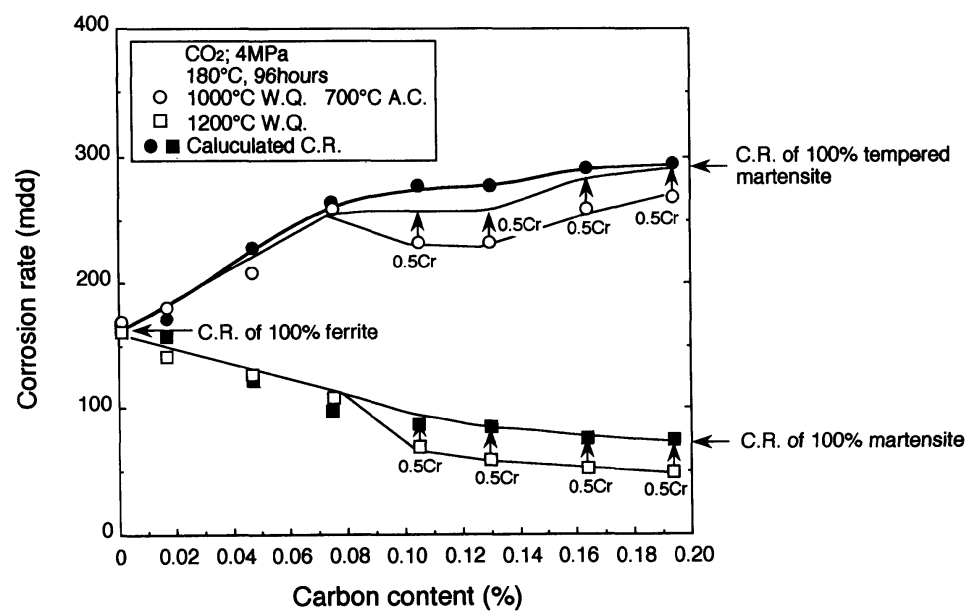

Fig.8 Comparison between calculated corrosion rate and experimental results. 


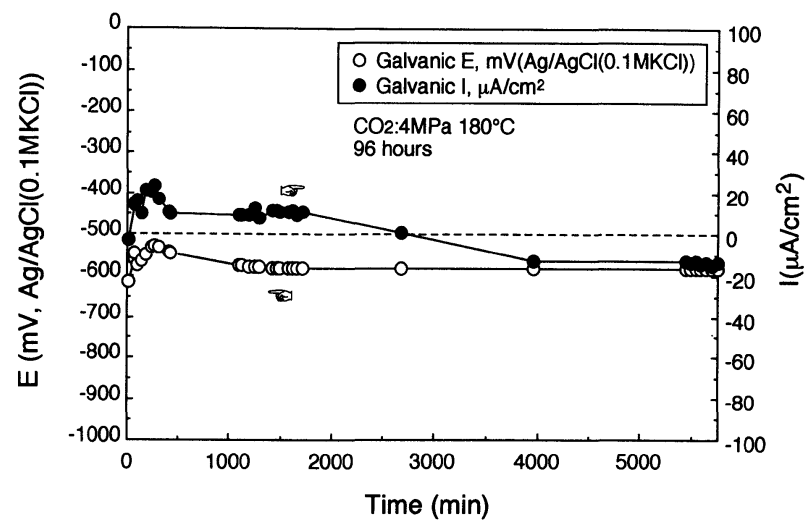

Fig.9 Galvanic current density and coupled potential as coupled $0.001 \%$ carbon steel and $0.2 \%$ carbon steel.

り, C 量が 0.2\%の焼戻し材の組織は 100\%焼戻しマル

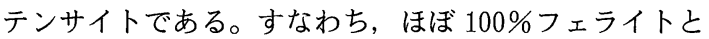
100\%焼戻しマルテンサイトをカップルさせている。試 験開始当初はガルバニック電流は $100 \%$ 焼戻しマルテン サイト材からフェライト材に流れている。その電流值は 最大で $20 \mu \mathrm{A} / \mathrm{cm}^{2}$ と非常に小さい。その後, 電流は減 少していき, 最終的には電流の流れは逆転し, 安定した。 最終的な電流值も $15 \mu \mathrm{A} / \mathrm{cm}^{2}$ と非常に小さい。従っ て，100\%焼戻しマルテンサイトと大部分 $100 \%$ のエ ライトとのガルバニック腐食は無視できるほど小さい。

\section{4. 考察}

\section{$\mathrm{CO}_{2}$ 腐食に及ぼす組織の影響}

今回試験した $\mathrm{CO}_{2}$ 分圧 $4 \mathrm{MPa}, 180^{\circ} \mathrm{C}$ 人工海水中で の腐食速度は組織によってその值が異なる。焼戻しマル
テンサイトの腐食速度が $1.37 \mathrm{~mm} / \mathrm{y}(295 \mathrm{mg} /$ $\mathrm{dm}^{3} /$ day）と最も大きく, 続いてフェライトの腐 食速度で, $0.79 \mathrm{~mm} / \mathrm{y}\left(170 \mathrm{mg} / \mathrm{dm}^{3} / \mathrm{day}\right)$, 最も 腐食速度の少ないマルテンサイトが $0.44 \mathrm{~mm} / \mathrm{y}$

(95 mg/ dm³/day) であった。すなわち，13\% $\mathrm{Cr}$ 鋼を湿潤 $\mathrm{CO}_{2}$ 環境中で用いた場合, フェライ 卜，焼戻しマルテンサイト及びマルテンサイトに よってそれぞれの腐食速度に差があることが判明し た。以下, 組織による腐食速度の差について考察し た。

0.194\%C の焼戻し材の電解抽出後の残渣を X 線 回折した結果を Fig. 10 に示す。 $\mathrm{Cr}_{23} \mathrm{C}_{6}$ が析出して いる。従って, 焼戻しによる $\mathrm{Cr}$ 炭化物の析出によっ てマトリクス中の $\mathrm{Cr}$ 量が減少する。 $\mathrm{CO}_{2}$ 腐食はマ

トリクス中の $\mathrm{Cr}$ 量で決まる ${ }^{1)}$ と考えられているの で, 同じ $\mathrm{Cr}$ 量の場合では $\mathrm{Cr}$ 炭化物を多く析出させた 方の $\mathrm{CO}_{2}$ 腐食性が劣化する。 $0.194 \% \mathrm{C}$ の焼戻しマルテ ンサイトの $\mathrm{Cr}$ 炭化物の量は $0.001 \% \mathrm{C}$ のフライトの $\mathrm{Cr}$ 炭化物に比べてはるかに多いと考えられるので焼戻 しマルテンサイトの腐食速度はフェライトよりも多いと 考えられる。

一方，焼入れまま材の場合では，マルテンサイトは 100\%C 量を固溶することができるのに対してフェライ 卜はC 量を固溶することができない11)。Fig.11にC 量 が $0.001 \%$, 熱処理条件(2)の析出物の電子顕微鏡写真お よびEDX 分析を示す。EDX 分析より $\mathrm{Cr}$ のピークが見 られることにより，フェライト中に Cr の析出物が存在 すると考えられる。 $\mathrm{Cr}$ の析出物は粒界付近に多く析出 している。0.001\%C の焼戻し材の電解抽出後の残椬を $\mathrm{X}$ 線回折した結果をFig.12 に示す。析出物は $\mathrm{Cr}_{2}(\mathrm{CN})$

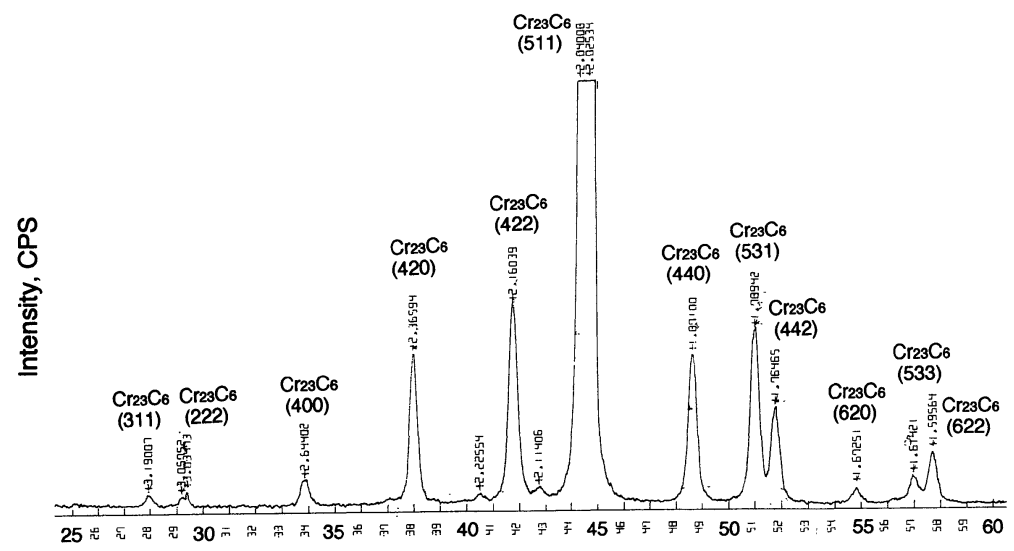

$2 \theta$, $^{\circ}$

Fig.10 X-ray analysis of tempered 13\% chromium steel after electrolytic extraction. 
である。よって, Fig.11での Cr析出物は $\mathrm{Cr}_{2}(\mathrm{CN})$ で あると考えられる。

以上の結果からコェライトの腐食速度がマルテンサイ トよりも大きくなる理由は以下のように考えられる。(1) 焼入れままの低C 鋼はフェライト粒界が腐食しているこ とおよびCr 析出物は粒界付近に多く存在したことから フェライト粒界およびその付近は Cr 欠乏層が存在する と考えられる。(2)フェライトのマトリクス中の Cr 量が Cr 析出物により低下している。(1)，(2)の理由からフェ

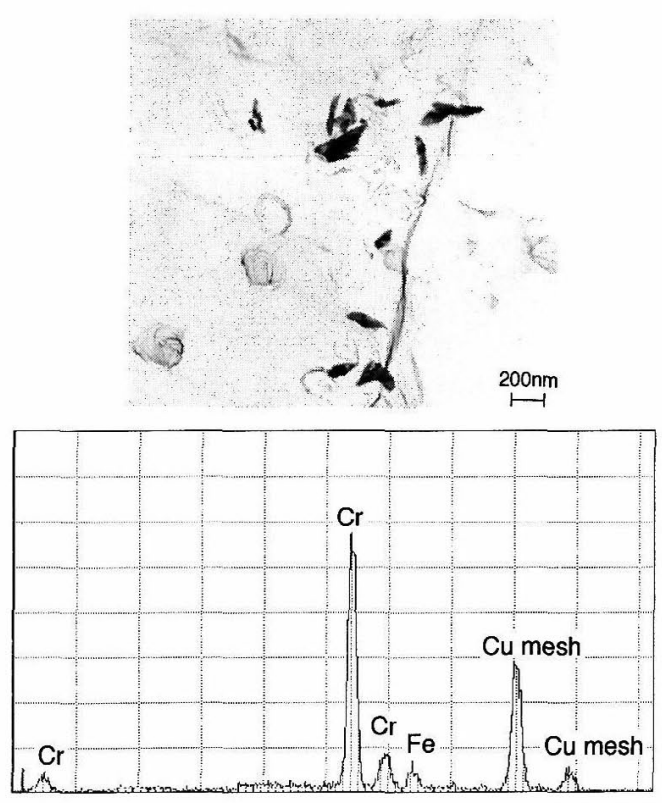

Fig.11 Transmission electron micrographs and EDX analysis of precipitate.
ライトの腐食速度がマルテンサイトよりも大きくなった と考えられる。この考察に関する立証は今後の課題とし たい。

以上の結果よりフェライト, 䡒戻しマルテンサイト及 びマルテンサイトによってそれぞれの腐食速度に差があ り，その腐食速度はマルテンサイト，フェライト，焼戻 しマルテンサイトの順に大きくなると考えられる。

\section{5. 結 論}

$13 \% \mathrm{Cr}$ 鋼の湿潤 $\mathrm{CO}_{2}$ 環境中での腐食に及ぼす $\mathrm{C}$ 量の 影響と金属組織の影響について検討し，以下の結果を得 た。

（1）フェライト，マルテンサイトおよび瑨戻しマル テンサイトの腐食速度は異なり，その腐食速度はマルテ ンサイト, フェライト, 焼戻しマルテンサイトの順に大 きくなる。

（2） $13 \% \mathrm{Cr}$ 鋼の腐食速度はそれぞれの組織の腐食速 度亡組織分率の積の和で表される。

\section{謝 辞}

本研究に有益なご助言と討論ならびに試料の提供を頂 きました金沢工業大学教授小川洋之博士，新日本製鐵 (株)鉄鋼研究所紀平寛博士，新日本製鐵(株)名古屋技 術研究部宮坂明博博士，新日本製鐵(株)八幡技術研究 部高橋明彦博士ならびに坂本俊治氏に心より感謝申し上 げます。

(Manuscript received May 27, 1998; in final form September 2, 1998)

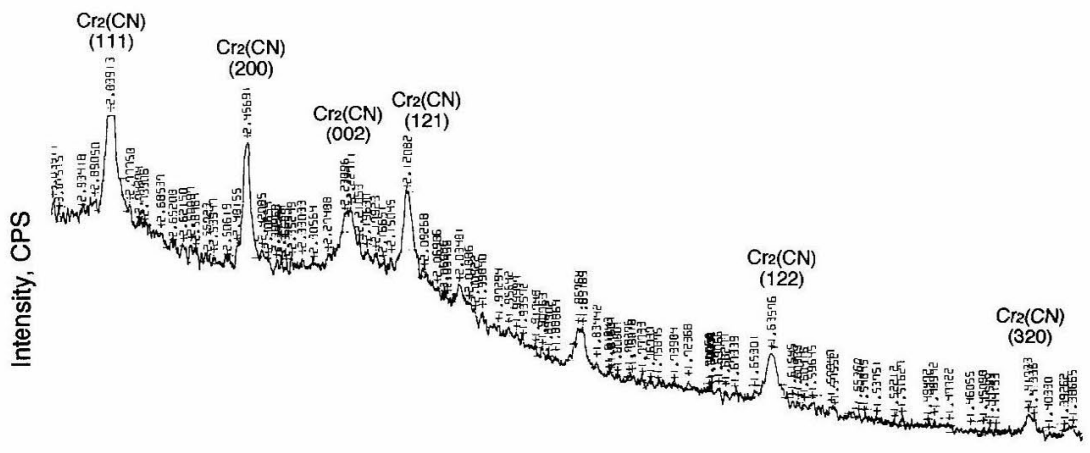

$\frac{1,1,1}{30 \bar{\pi} \approx \pi}$

$2 \theta,^{\circ}$

Fig.12 X-ray analysis of tempered 13\% chromium steel after electrolytic extraction. 


\section{参 考 文 献}

1）川上 哲, 朝日 均, 上野正勝 : 材料とプロセス, 6, 696 (1993).

2) A. Tamaki: CORRSION/89, Paper No.469, NACE International Houston, Texas (1989).

3 ) A. Miyasaka and H. Ogawa: CORROSION/ 90, Paper No.97, NACE International, Houston, Texas (1990).

4) M. Ueda, T. Kushida, K. Kondo and T. Kudo: CORRSION/92, Paper No. 55, NACE International, Houston, Texas (1992).

5 ) S. Hashizume, T. Takaoka, Y. Minami and Y. Ishizawa: CORRSION/92, Paper No. 54,
NACE International, Houston, Texas (1992).

6) H. Asahi, T. Hara, A. Kawakami and A. Takahashi: CORROSION/95, Paper No.79, NACE International, Houston, Texas (1995).

7 ) 小川洋之: 西山記念講座, 石油掘削用耐食材料, p.19, 日本鉄鋼協会 $(1990)$.

8 ）植田昌克: 材料とプロセス，9，1391 (1996).

9 ) 高部秀樹, 植田昌克 : 材料とプロセス, 10, 1437 (1997).

10）ステンレス鋼便覧一第 3 版一，p.99，ステンレス 協会 (1995).

11) E. Baerlecken, W. A. Fischer and K. Lorenz: Stahl u. Eisen., 81, 768 (1961). 